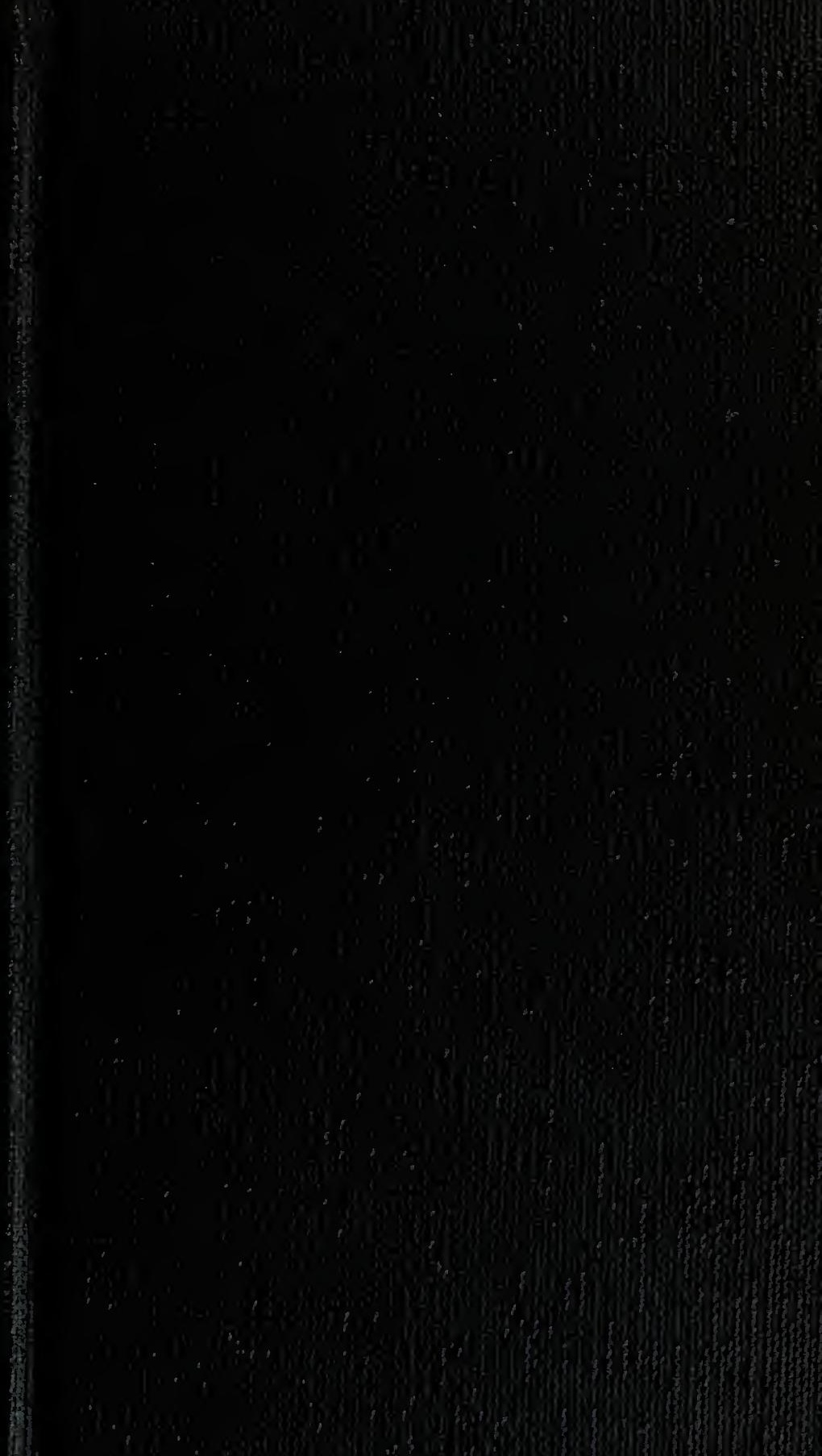


ment"

पु

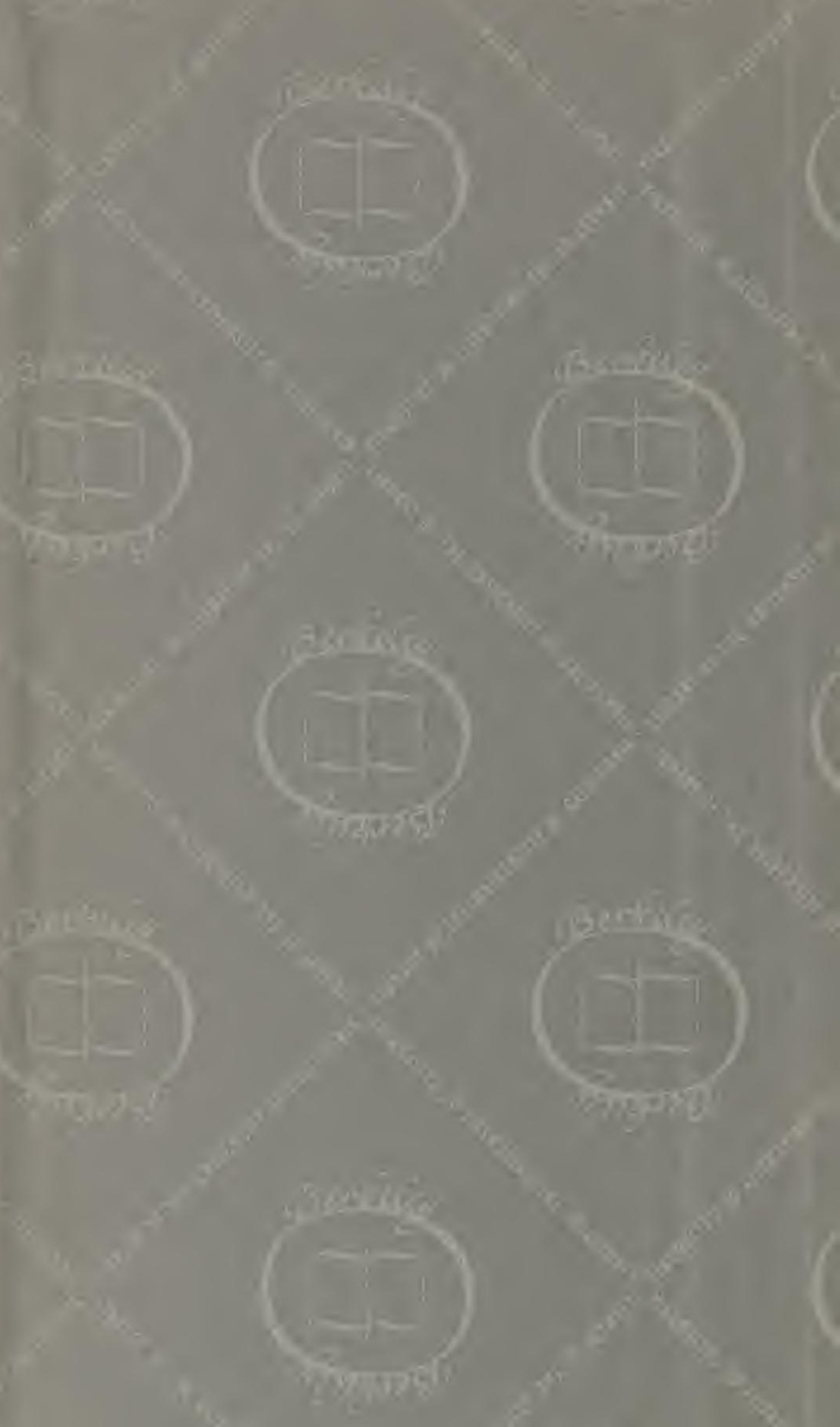




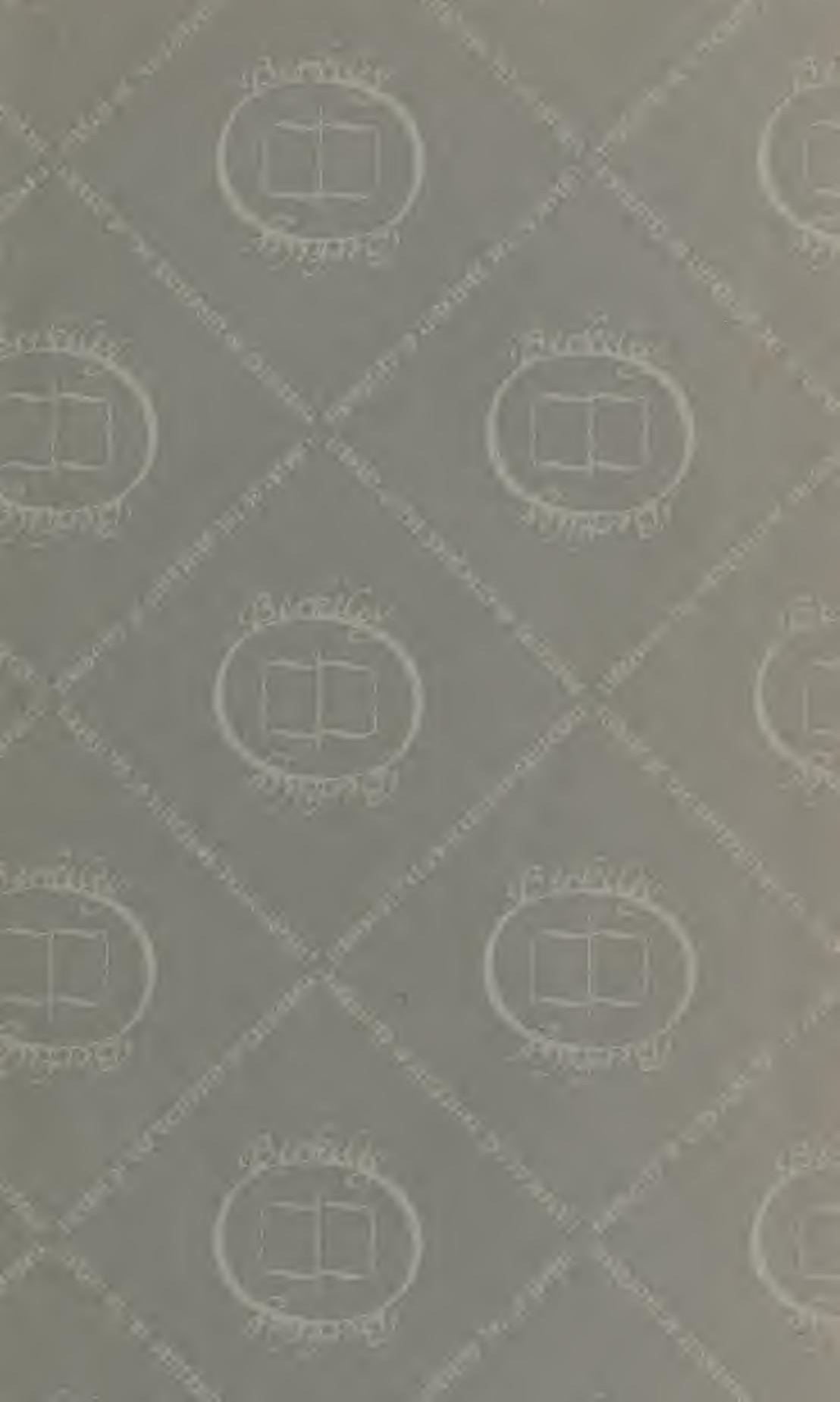





\title{
Writh the complaiments of the author.
}

\section{THE PENNSYLVANIA-GERMAN}

\author{
IN THE
}

\section{Field of the Natural Seienses ... BY ...}

\author{
THOMAS CONRAD PORTER, \\ OF LAFAYETTE COLLEGE.
}


Digitized by the Internet Archive in 2007 with funding from Microsoft Corporation 


\section{THE PENNSYLVANIA-GERMAN}

\section{IN THE \\ Field of the Natural Seiensps \\ .. BY ...}

THOMAS CONRAD PORTER,

OF LAFAYETTE COLLEGE.

Carolus Linnaeus, or Karl von Linne, the most illustrious student and reformer of modern times in the domain of natural history, was born in I7O7, at Raeshult, a village in the south of Sweden. Having fought his way against great odds from a low estate up to fame and fortune, the period of his productive activity as a scientist extended from the year 1736 to the day of his death in I778. In I74I he attained the highest goal of his ambition, when called to the Chair of Botany in the University of Upsala and raised to the rank of the hereditary nobility of the realm.

Linnaeus was an indefatigable toiler, not in the 
closet only, but in the field also. In the early part of his career he traveled over a large portion of the Scandinavian peninsula, gathering rich spoils, and, later, supported by royal patronage, sent forth not a few of his young disciples, to bring back from distant lands like treasures to the museum of the University. These it became his business to examine, describe, name, figure, classify and give permanent record in a long series of publications, which contain articles pertaining to chemistry, mineralogy and zoőlogy, although botany holds the chief place.

The impression produced by such achievementsan impression that has not yet spent its force, but continues to inspire and stimulate scientific research in new lines and channels all the world over-was then felt far and wide amongst his contemporaries in Europe. By reason of his presence at Upsala, the number of students in the University rapidly rose from 500 to 500 . And the attractive power reached beyond the Atlantic, for, in a list of a party of seven, who under his leadership made an expedition into the province of Dalecarlia, occurs the name of Sandel, "a Pennsylvanian." One of his disciples, Professor Kuhn, delivered courses of lectures on botany in Philadelphia, and the great master has perpetuated his memory in the genus Kuhnia. And another of them, the Swede, Peter Kalm, visited our shores, devoted a good deal of time to the investigation of the flora of southern New Jersey and southeastern Pennsylvania and the results of his observations are embodied in a work, which has been translated into 
English. Him likewise, the master honored by giving his name to a genus of shrubs (Kalmia), the largest species of which abounds on our hills and mountains, conspicuous for its shining, evergreen foliage and clusters of beautiful flowers. Popularly known as "Mountain Laurel," it is deemed by many worthy of being chosen for the heraldic emblem of the nation.

But the Linnaean influence on the Germans of Pennsylvania has borne richer fruit.

Henry Muhlenberg, or, as his full baptismal name reads, Gottlieb Heinrich Ernst Mủhlenberg, son of the Rev. Heinrich Melchior Miihlenberg, the patriarch of the Lutheran Church in the United States, was born in Montgomery county, in the year I753, and sent, in 1763 , with his two older brothers, to Halle, in Germany, to receive there such linguistic and theological culture as would fit them for the office of the holy ministry. After an absence of seven years, he returned home in 1770 , and, ordained by the Synod at the early age of 17 , became the assistant of his father in serving congregations in and around Philadelphia. In I777, on the approach of the British troops to that city, he was compelled to flee, because he and his kinsfolk had become particularly obnoxious to the Tories on account of their patriotism. At length, in I780, he accepted a call to Trinity Church, Lancaster, and remained there till the day of his death in May, I8I5.

This then was the theatre both of his pastoral and scientific labors for the long period of 35 years. His 
interest in the plant-world, no doubt enkindled or strengthened, during his residence in Halle, when the star of Linnaeus was in the ascendant, now became active and grew stronger and stronger to the end of life. Not only was the county of Lancaster thoroughly explored by him, but he opened and kept up an extensive correspondence and exchanges with the most eminent botanists of his day in Europe and America, and the superior excellence of his work won ample acknowledgment from many learned men and societies.*

The printed works upon which rests the fame of Muhlenberg, as a botanist, are only two in number, neither of them voluminous, and yet of the highest value to the students of our flora. The first bears the title: "Catalogue of the hitherto known native and naturalized Plants of North America," and came from the press at Lancaster under his own supervision, in I8I3; the other: A Fuller Description of the Grasses and Sedges of North America, indigenous and naturalized," in Latin, with a preface by his son Frederick, was published in Philadelphia in I8I7, two years after his death.

The Catalogue is a great deal more than the simple title imports, because it embraces condensed and abbreviated descriptions, from which the species meant can be generally identified. In both works, however,

*A full account of this phase of his life is contained in an admirable paper in the German language from the pen of the late Professor J. M. Maisch, of the Philadelphia College of Pharmacy, read before the Pionierverein in ISS6, of which an English translation ought to be made and published. 

PROCEEDINGS PENNSYLVANIA-GERMAN SOCIETY, 1896.

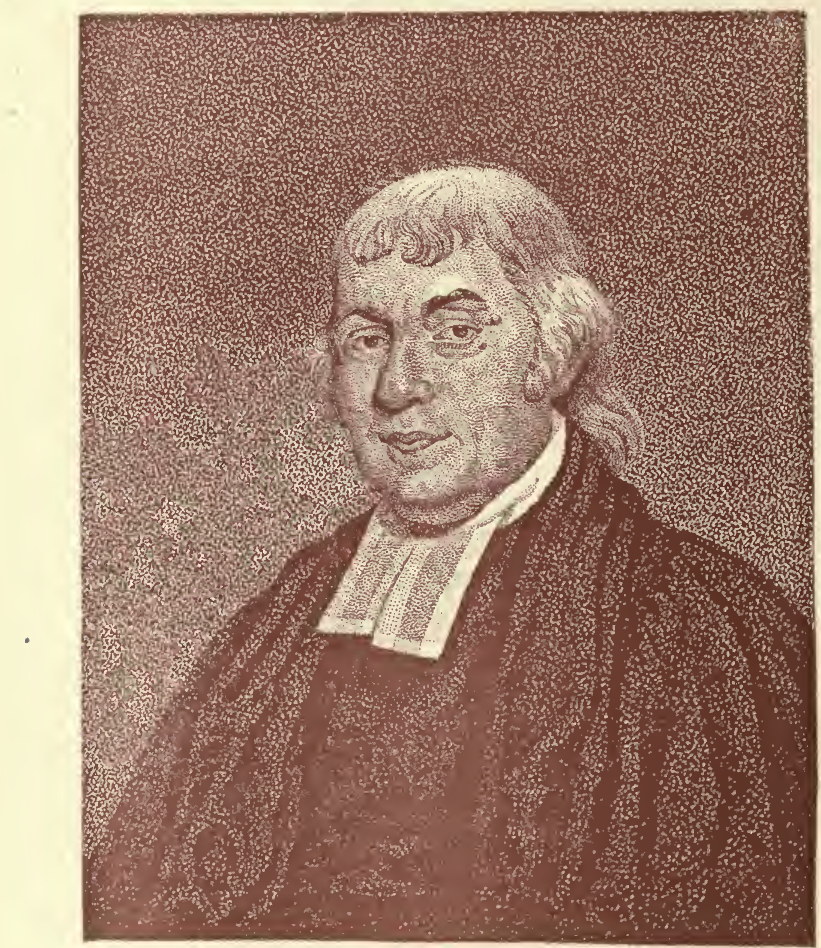

Patle pure.

Gueman \& Pigye

Herer. Muhlenberggun. 1776 


\section{Dr. Porter's Address.}

the territory assumed is much too large. With but few exceptions, the plants belong to the Atlantic slope of the United States. At that time little was known of the flora of the regions beyond the Mississippi, or even the Alleghenies. The number of new species discovered and described by the author is about Ioo, nearly all phanerogamous or flowering plants. But, if the 80 described by his correspondent Willdenow, most of which, at least, were obtained from him as the collector, be counted in, the extent of his contributions to science can be measured. No single one of the early botanical explorers of our eastern field, except, perhaps, Michaux, did so much, and what he did was well done and will endure.

Outside of a circle purely scientific, there are really few who understand and appreciate such labors, and yet, strange as it may seem to the multitude, there is no other kind of work that is likely to carry a man's name and fame further down the coming ages. Muhlenberg, the eloquent preacher and faithful pastor, may in the far future cease to be held in lively remembrance; Muhlenberg, the botanist, cannot pass out of view, and be neglected or forgotten, because he has left his broad impress on Nature's handiwork and Nature never forgets those who love her.

In the records of the plant-world a personal name may be carried in three ways ; first, when used to denote a species, for instance, Quercus Muhlenbergii (Muhlenberg's Oak), so called because he discovered and brought it into notice; second, when attached to a species which he has named and described, and 
in this category Muhlenberg has at least roo species to speak for him; and third, when embodied in a genus, as was done, when Professor Schreber created the genus Muhlenbergia, to include a large group of beautiful grasses, seven of which flourish all around us in our fields and meadows, and the remainder in the Rocky Mountains, California and Mexico.

Sometimes such generic names are made to honor persons famous in other ways, wholly apart from any service done in the development of botanical science. Thus, Queen Victoria of England, is forever associated with a magnificent water-lily, or lotus, of South America, which has a permanent place in all large conservatories and bears her full name-Victoria Regina. A stately tree of Japan, with large leaves and blue flowers, allied to our catalpa, and widely cultivated, commemorates a Russian princess, as Paulownia imperialis. Gay Lussac, the French chemist, has his tribute of honor in the Gaylussacias, and Thomas Jefferson, a friend and patron of the natural sciences, in his Jeffersonia diphylla. But the most remarkable example of the kind is found in the gigantic red-wood of the Sierra Nevada of California - the celebrated Sequoia gigantea, which has a sister species, (S. sempervivens) along the Coast Range of the same state. The English botanists, in order to honor the hero of Waterloo, tried to have Wellingtonia adopted instead of Sequoia, but the latter had the precedence, and hence in all time to come the tree will bear the name of Se-quoi-yah, the Cherokee Indian, who invented a syllabic alphabet for the use 
of his tribe. He was not a savage chieftain, adorned with war paint and feathers, and rejoicing in deeds of blood, but one who strove to elevate his race by the arts of peace, and, as its best representative, will keep alive the memory of our aborigines long after they have passed away, leaving behind them only a few relics and geographical names, which, when interpreted, show that they were all derived from the natural peculiarities of the objects named, and not one of them from persons or historical events. The Government has wisely extended its protecting aegis over the Sequoia-groves of the Sierra Nevada and set apart a reservation of 5000 acres, which the axe or saw of no lumberman dares invade. And there the younger trees may grow and flourish, without molestation, until they reach the size and age of their mighty ancestors which now tower up toward heaven in the very places where their seeds germinated 12 or 15 centuries ago.

Compared with monuments like these, what are the statues of bronze and piles of chiseled stone, by which men have hoped and still hope to secure an earthly immortality? The temples, palaces and sculptured gods and goddesses of ancient Athens have nearly all crumbled into dust or been reduced to fragmentary ruins, amongst which the busy antiquarian gropes to find traces of former beauty and grandeur, whilst the patches of wild thyme, on the slopes of Mount Hymettus near by, still bloom, unchanged and fresh and odorous, yielding their stores of honey to innumerable bees, just as they did more than 2000 
years ago. And, even when monuments reared by human hands do survive for many centuries, they often fail to tell why and for whom they were erected. An old writer quaintly remarks: "The pyramids, doting with age, have forgotten the names of their founders." But life in Nature must triumph over oblivion, by reason of perpetual re-creation and renewal.

If then the plant-world is able to preserve and carry down to posterity the memory of persons otherwise famous, it will certainly do much more for those who, like Muhlenberg, have been closely associated with it in a scientific way. And here, in one respect, he has been fortunate above his fellow-workers. A botanist may deal with collections gathered in remote countries and win renown among the few advanced students who seek his books in libraries or pore over the dried specimens in his herbarium, or else he may devote his time to the illustration of obscure orders, which for their inspection require high powers of the microscope. But the case is far different when the plants are conspicuous and abundant, and constitute a large portion of the flora of the woods, fields and swamps of a thickly-peopled region like that of our eastern states. Then they are sure to attract, in their living forms, generation after generation of amateurstudents, children of the schools, skilled botanists and those who may be drawn to cultivate them for their beauty or utility. Hence, the asters and the golden-rods, the sedges and the grasses, which Muhlenberg saw, handled and described, and of whose ex- 
$$
\text { . }
$$ 
PROCEEDINGS PENNSYLVANIA-GERMAN SOCIETY, 1896.

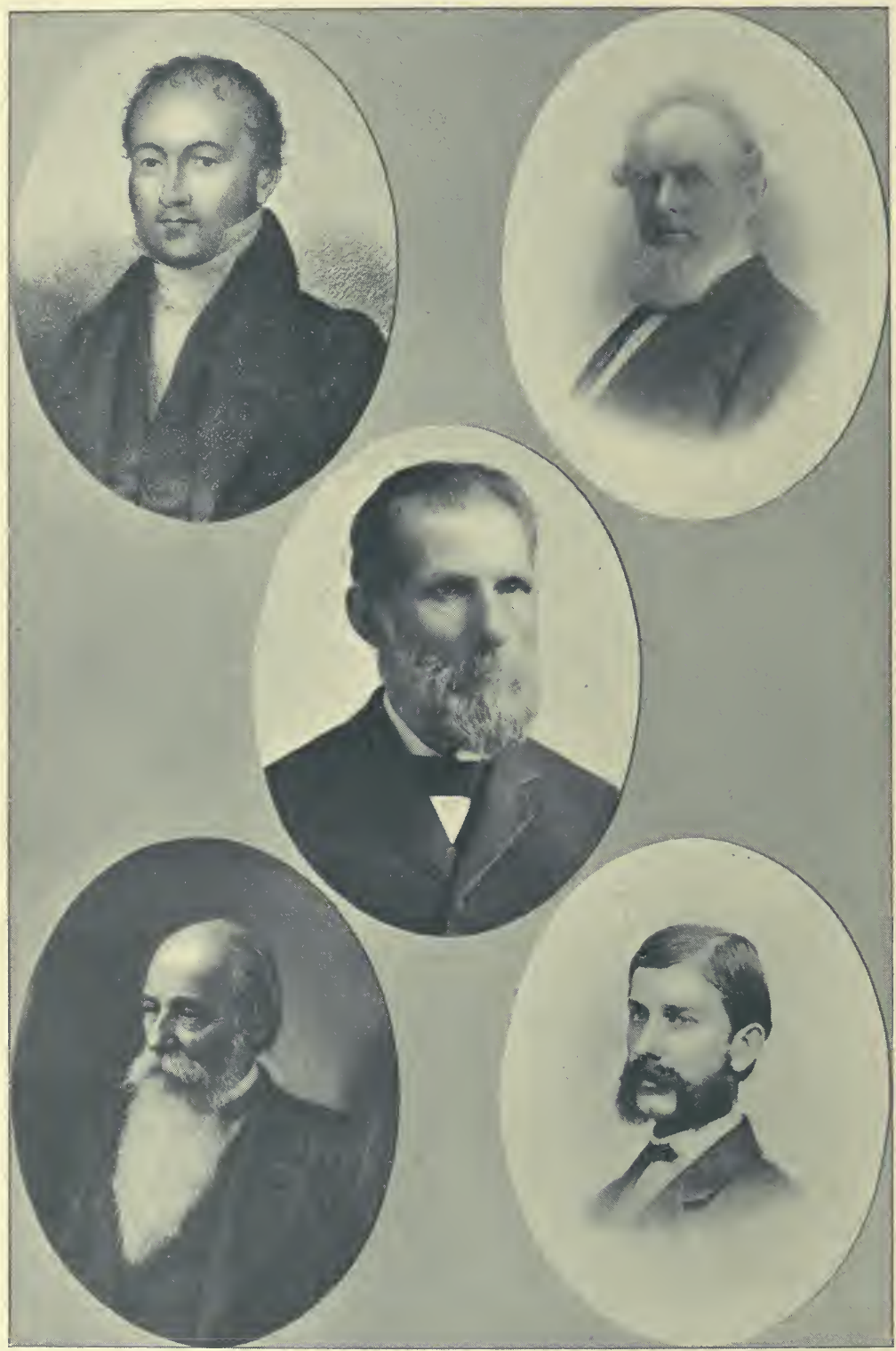

L. D. VON SCHWEINITZ.

FRANCIS WOLLE.

8. S. HALDEMAN

S. S. RATHVON.

A. P. GARBER. 
tirpation in the future there is not the slightest danger, will bring his name up before thousands in the coming ages and prompt them to learn from other sources all they can of his personal history.

In I780, the year of Muhlenberg's settlement in Lancaster, another great Pennsylvania-German naturalist, the Rev. David Lewis von Schweinitz, was born at Bethlehem. His father was of an ancient and distinguished family of Silesia and his mother a grand-daughter of Count Zinzendorf. Designed for the ministry in the Moravian Church, his early education was received in the school at Nazareth, where he exhibited an enthusiastic fondness for cryptogamic botany. In $\mathrm{I} 778$ he went to Europe with his father, for the purpose of fuller classical and theological training at Niesky in Upper Lusatia. There he devoted his leisure hours to the Fungi, and, in conjunction with Professor Albertini, published at Leipsic a volume on the species of the order discovered around Niesky, for which, as a mark of appreciation, the degree of $\mathrm{Ph}$. D., was conferred upon him by the University of Kiel. On his return to America, in I8I2, he was appointed general agent of his Church in North Carolina and in this new field continued his labors, the results of which were printed at Raleigh in 1821. Ten years later, his great work, " $A$ Synopsis of the Fungi of North America," was presented to the American Philosophical Society of Philadelphia, and in it the number of species enumerated or described is 3098 , including $\mathrm{I}_{20} \mathrm{O}$ new to science. During the same period he prepared his well-known 
"Monograph of the Carices of North America." Read before the New York Lyceum of Natural History and accepted, it was placed in the hands of Dr. John Torrey for publication, because duty called the author across the Atlantic. It was, therefore, edited by Dr. Torrey, with some additions, and for this reason, Schweinitz generously insisted that it should appear as a joint production.

Like Muhlenberg he too has been honored by having his name embodied in a genus of flowering plants of the Heath Family, Schweintzia, represented by a brace of rare species, one of them at home in the mountains of the Carolinas, and the other in Florida. The study of nature by these two accomplished scholars and divines was not inspired by a lust for worldly gain, or worldly ambition, nor a love for mere utility, amusement or recreation, since it was pursued earnestly, steadily and methodically from the days of boyhood through all the riper years of their busy lives. That it was ever permitted to interfere with the discharge of the duties of their sacred calling cannot be supposed. Indeed, in this regard, it must have proved an invaluable help instead of a hindrance, for they no doubt recognized the truth that the revelations of God in His works and in His word are at bottom one, and hence, that both are needed as moulding factors for every man who aspires to full moral and mental stature, to say nothing of his best physical well-being. Our Maker speaks to us, if we have but eyes to see and ears to hear and hearts to feel, through the lilies and the 
roses, as well as in the thunders of the law. St. Paul says that the natural comes first and then the spiritual, and a neglect of this cardinal principle has been the occasion of immense mischief in human culture. A thorough knowledge of the lower world of nature alone can prevent or cure tendencies to vague and wild speculation in the higher spheres of philosophy and religion.

The death of Schweinitz, at the age of 54, occurred on the 8th of February, I834, and a memoir of his life and scientific labors was prepared and read by Mr. Walter R. Johnson before the Academy of Natural Sciences in Philadelphia, and published by him (with a portrait) at the request of the Academy.

Although Shakespeare does say:

"The evil that men do lives after them;"

and then adds, by way of contrast,

"The good is oft interred with their bones;"

it has not been so here. Among the brethren of his own community, in this very town of Bethlehem where he was born, the seed sown by Schweinitz has continued to produce fruit of the same kind and in the same realm of cryptogamic botany in which he labored. Of this a striking testimony is afforded by the superb works on our Fresh-water Algae, from the pen and pencil of the late Rev. Francis Wolle, which have won for him such an enviable place in the annals of American science.

In like manner the example and influence of $\mathrm{Muh}$ lenberg survived in the chief field of his activity, and there is perhaps no county in the United States, whose 
flora, fauna, minerals and rocks have been more thoroughly studied than those of Lancaster,as can be shown by the collections of the Linnaean Society and its records published in the History of the Rev. Dr. Mombert. Now, the men who accomplished all this were of the native German stock, and amongst them, Simon S. Rathvon, will long be held in high esteem for services done in those branches of entomology to which he devoted special attention.

Born also in Lancaster county, where his life was spent, and a scion of the same stock, ever proud of his descent, was the brilliant, witty and genial Professor Samuel Stehman Haldeman, one of the most industrious, original and profound scholars of the century. He began his career as a naturalist and published a work on our "Fresh-water Shells," now out of print and much sought after, but soon passed over to linguistic and philological studies in which he achieved great distinction, both at home and abroad. Agassiz said of him, "That man Haldeman has an idea behind every word that he utters," and Dr. Francis A. March has written of him, "Professor Haldeman was in early life a naturalist and by his mental constitution a scientist, and he took hold of the forms of speech in the same spirit," and "we shall never look upon his like again."

Another Lancaster-county naturalist of German descent who deserves notice is Abram Paschal Gar-

*There is an interesting memoir of this distinguished man, by Charles Henry Hart, in the Penn Monthly of $189 \mathrm{I}$, but what is needed is a full biography for which abundant material could be supplied by his family. 
ber. He was born on his father's farm near Columbia in 1838 , and his love of nature dates from early childhood. After taking a course of instruction in the Normal School at Millersville, he entered Lafayette College, from which he received the degree of $\mathrm{B}$. S. in I868. Here, without neglecting the duties of the class-room, all his available time was spent in ranging through the fields and woods around Easton in search of minerals and plants, and when, at a later period, he attended lectures in the Medical Department of the University of Pennsylvania, two of his summer vacations were employed in exploration and collection for the herbarium of the college, in the northern tier of counties and those west of the Alleghenies. Having attained the degree of M. D., he accepted the position of assistant-surgeon in the State Hospital for the Insane at Harrisburg, but forced by failing health to give up the practice of his profession, he sought relief in the warmer climate of Florida, where for two years he traveled extensively and made large collections of rare plants, a number of them either new to our flora or new to science. To one of these the distinguished botanist, Dr. Asa Gray, gave, to honor him, the name Garberia. But, alas! the milder atmosphere and living in the open air, although they no doubt prolonged his days, did not suffice to cure his malady and he came north again, to die at Renovo, Clinton county, in the year I88I.

Amongst the Pennsylvania-Germans of the present time, there are not a few whose excellent work in the various departments of the natural sciences will be 
acknowledged and chronicled hereafter, but this brief historical sketch is restricted to those who have already finished their labors, and of these, the foremost representative, the one who has accomplished most and achieved the greatest fame, a fame that will grow clearer and brighter as the years roll by, is, beyond doubt, Joseph Leidy. His great-grandfather, Carl Leidy, came from Rhenish Germany, early in the eighteenth century, (about I $^{24}$ ) and settled in that part of Penn's province which included Montgomery and Bucks counties. He was born in Philadelphia in I823. His parents and kinsfolk, all German and speaking the German language, belonged to the Lutheran Church. When quite young he displayed an extraordinary interest in natural objects. Minerals and plants first attracted him, but his mind soon turned to the animal kingdom, the study of which as a whole, from the human body and vertebrates in general, both living and fossil, down to the minutest microscopic organisms, was pursued with a rare and simgle-hearted devotion and with marvellous success up to the period of his death in I89I.*

Now, the peculiar qualities which so admirably fitted Dr. Leidy for his splendid career were evidently derived from his German ancestry. And they are manifest also in all the others who have been named in this paper. Over them, however, he had the ad-

*A full account of his life and labors can be found in a memoir by W. S. W. Ruschenberger, M. D., printed in the Proceedings of The American Philosophical Society and distributed by him in a separate pamphlet form. 
PROCEEDINGS PENNSYLVANIA-GERMAN SOCIETY, 1896.

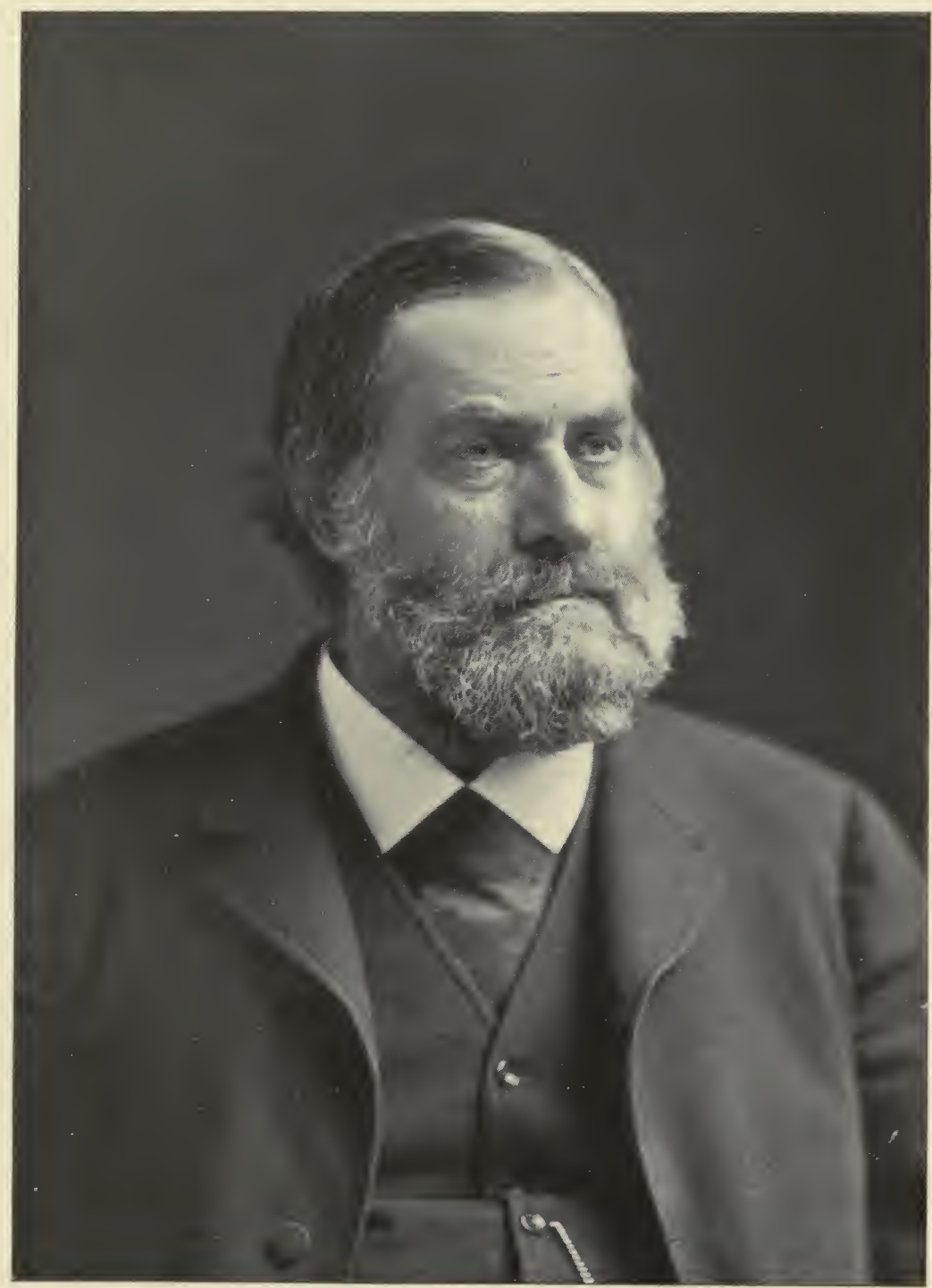

JOSEPH LEIDY. 

vantage of a more favorable environment. There was nothing to divert him from his chosen path, for, although the degree of M. D. was conferred upon him by the University of Pennsylvania, whose chair of anatomy he filled with such marked ability and honor, he never became a surgeon or physician in active practice.

The traits of character here referred to may be thus summed up-honesty in the broad and best sense of the word; the love of knowledge for its own sake and not primarily or solely for its useful applications, or as a means for gaining publicity or acquiring wealth; modesty that shrinks from blowing its own trumpet; a freedom from jealousy and envy; a readiness to help others engaged in the same pursuits; a preference for the real and substantial over against the theoretical and visionary ; inexhaustible patience and perseverance; and above all, an intuitive genius for method and order.

If these, three of our eastern counties can boast of a group of men like these, who have done so much in but a single department of the modern sciences, it certainly furnishes good ground for laudable racepride, and ought to put to shame that ignorant and vulgar class of our country men, who are wont to hold German Pennsylvania in much the same regard as Boeotia was held by the ancient Greeks. 
